\title{
Brand the Pricing: Critical Critique
}

\author{
Syed Hasnain Alam Kazmi ${ }^{1}$ \\ ${ }^{1}$ School of Economics and Management, Southwest Jiaotong University, Chengdu, Sichuan, China \\ Correspondence: Syed Hasnain Alam Kazmi, School of Economics and Management, Southwest Jiaotong \\ University, Chengdu, Sichuan, China. Tel: 86-159-0284-4074. E-mail: hasnain@my.swjtu.edu.cn
}

Received: April 15, 2015 Accepted: May 2, $2015 \quad$ Online Published: May 31, 2015

doi:10.5539/ijms.v7n3p125 URL: http://dx.doi.org/10.5539/ijms.v7n3p125

\begin{abstract}
Brand pricing decision models and established theories in the marketing and econometrics focus typically on assuming the symmetric competing businesses. The empirical generalities are key for strategic marketplace planning. The significance of pricing to customer store and brand choices are always regarded as a widely known truth among marketing scholars and explains consumer's role responding to their psychological representations of price rather than price itself. Scholars have highlighted simple but earlier unrecognized marketing practices that managers can employ to cultivate the positioning of their prices. Many theoretical researches in promotions have focused its aspects on developing powerful pricing strategies and its impact on consumer decisions, which is might because much of the literature has focused on building and evaluating price promotion strategies. This review experiential will enlighten us on advancements that will also lead us for optimistic cross-brand category level, cross-cultural level and cross-national level influences in pricing strategies.
\end{abstract}

Keywords: psychological, promotion, theory, consumer, brand, sales promotion

\section{Introduction}

\subsection{The Perceptions of Consumers}

The significance of pricing to customer store and brand choices is regarded as a widely known truth among marketing scholars and explains consumer's role responding to their mental representations of price rather than price itself. Thus, it can be evaluated that consumer price perceptions will influence purchase prospects, (Lichtenstein, 2014). For this purpose, many research scholars investigate contextual impacts that make prices perform favorable to consumers. Many Scholars like, Hamilton and Chernev (2013); Miniard et al. (2013); Chen et al. (2012) and Biswas et al. (2013) deliver valuable insights into many aspects that apply this kind of contextual and perceptual impact from store and product level to brand level. Hamilton and Chernev (2013) and Miniard et al. (2013) explore the customer's aspects from price inferences and study types of observable pricing to non-pricing associated information customers when understanding vital but unobservable prices, such as at store level and at competitors' level prices. Chen et al. (2012) and Biswas et al. (2013) study the impact of promotional pricing demonstration on buyers' numerical way of (price) information processing.

\section{Literature Review and Developments}

Donald Lichtenstein (2014) discuss on price inference that shoppers make it as store's level pricing level the higher price or the lower price store. Such in-depth observations from consumers have a prominent influence on store choice and on the susceptibility to search economical stores for lower prices. Hamilton and Chernev (2013) have developed a conceptual framework model for consideration of both price and non-price associated stimuli that are underneath the control of retailer and can directly affect the price image of retailer.

\subsection{Models Examination and Critique}

Miniard et al. (2013) examine the shopper price inferences on retailer practice are that of "partially comparative price", famous and huge retailer like, Walmart offers shelf labels for its products and brands that compare the pricing with that offered by the competitor/s (e.g., Toys "R" Us). Earlier examinations have shown that pricing judgments result in favorable pricing acuities for the referred brands or/and products.

Nevertheless, such judgements have shown to have the unintentional significance of leading to buyer inferences of the upper prices for advertising retailer (such as; Walmart) across product level categories in which prices are not associated (Barone, Manning \& Miniard, 2004). This issue address is negated by Miniard et al. (2013) and 
discovers that when comparative prices castoff on a brand in a product class level, the customers perceive the other brands in the product level category to be priced more favorably than named competitor's price/s. Nevertheless, in context with the principle that comparatively priced product/brand in a category is the norm, if vender compares prices on more than one product/brand in the category, customers will surmise that the selected product/brand is opted, and the spillover effect to other products/brands models in the product category line will be diluted.

Chen et al. (2012) explain the model concept that how price perceptions influence consumers' abilities and norms in form of numerical processing information. The model shows that customers are weak processors of numerical processing values, which presented in terms of some percentages. The author advances the model in term of "base value neglect" model method (BVN). This concept represents that consumers' tendency to neglect the base value to which percentages are applied and focus on the special judgments solely on which percentages itself. The author focuses this context and plays out in using an experimental manipulation in his work and explain that in marketers' selection to provide bonus packs or amount of brand/product (50\% more) versus lower price (33\% off) in context to promotional activity. For instance, if product costs $\$ 12.00 /$ pound, marketer would offer some promotion of about $50 \%$ more ( 24 ounces) in it or will sell the pound at a rate of $33 \%$ off $(\$ 8.00)$. In both circumstances, the effective price wil be $\$ .50$ /ounce. Nevertheless, customers will overwhelmingly prefer bonus amount as because the percentages $50 \%$ is greater to $33 \%$. Consumers will simply snub the changes in the base values of (16 ounces, to $\$ 12.00$ ) when developing their special preferences on it.

\subsection{Critical Developments}

Author like, Biswas et al. (2013) enlighten on the method of "subtraction principle" to discover the consumers' reactions to how price discounts. For instance, retailers usually advertise the promotional prices in a way like “Was \$99.95, and Now only in \$52.95." In such circumstances, consumers simply subtract the second part of price from the first one and recognize that the retailer is going to offer discount of high value of $\$ 47.00$. However, many type of campaign by listing the lower sale price at first point is followed by higher reference price, such as "Sale on $\$ 52.95$, earlier was $\$ 99.95$." As the former approach of presentation is consistent with how people will first learn, the subtraction amount (with the larger number on the left), it will be convenient for consumers to "do the math," easily and they are more likely to execute the calculation than in the latter situations. The authors call this propensity as "subtraction principle." When selling price is listed first and the reference price second, the consumers are less expected to perform the calculation and instead simply just come to default to assuming that it has a $10 \%$ to $15 \%$ discount. Therefore, it is taken in to account when the discounting is very low (at e.g., 5\%) and consistent with subtraction principle.

Some scholars highlight simple but earlier unrecognized marketing practices that executives can employ to develop the positioning of their prices like; Hamilton and Chernev (2013); Miniard et al. (2013); Chen et al. (2012) and Biswas et al. (2013). For instance, one pervasive promotional practice is the use of reference price promotion. Reference prices are shown to have an influential impact on consumer responses across brands and to product contexts. Nevertheless, scholars further develop their influence that advertisers should design their promotion activities so that the reference price is positioned above in context to or to the left side of the sale price, rather than to the right side or at its below. In addition to it, managers are habitually to use the on-shelf exhibitions to show that their price is lower than some opponent's price on an item. In the enthusiasm to make lower price views, managers may believe that it works identical for all products and they can diminish the favorable price perceptions from the offers.

All of these tools will encourage the "general perceptions" of store prices, which may be the furthermost influential factor in getting shoppers to the stores in the first place. Many theoretical researches in promotions have focused its aspects on pricing and its impact on consumer decision making, which is might because much of the literature has focused on building and evaluating price promotion strategies. Theoretic models are discussed, which are used for the study of price promotions.

\section{Pricing Simulations}

Many theoretical researches in promotions have focused its aspects on pricing and its impact on consumer decision making, which is might because much of the literature has focused on building and evaluating price promotion strategies. Scholars have studied the impact of price promotion strategies on consumers' reference internal pricing (Lattin \& Bucklin, 1989; Kalwani \& Yim, 1992) and its impact of relative price advertising on the buyer sensitivity of savings obtained from promotions (Bearden, Lictenstein \& Teel, 1984; Buil et al., 2013a, b). Theoretical based approaches, which mainly enlighten on pricing aspect of promotion, include Theories of Adaptation level, Assimilation Contrast, Self Perception Theory, Objective Perception Theory, Prospect Theory, 
Mental Accounting Theory, Theory of the Reasoned Action, Theory of Planned Behavior, Theory of Attribution, Transaction Utility, Attitude Model, and Model of Elaboration Likelihood. These advancements will also lead us for optimistic cross product category, cross cultural and cross-national influences on promotion strategies.

\subsection{Consumer Behavior to Promotions}

Researches in marketing psychology have focused on consumer reaction to campaigns using some experimental approaches to it (e.g., Dodson et al., 1978; Kahn \& Raju, 1991), and econometric investigation of secondary data (e.g., Jain \& Vilcassim, 1991; Buil et al., 2013a). However, few scholars have endeavored for understanding consumer response to promotions using theoretical decision-making strategies and models, such as work of Assuncao and Meyer (1993) and Buil et al. (2013b). Theoretical developmental models of price promotions (Lal, 1990a; Rao, 1991; Buil et al., 2013b) provide enlightenments for the pervasiveness of price discounts in conventional marketplaces.

\section{Pricing and Branding}

Gordon Wyner (2014) discusses that pricing is the marketing pedal with the utmost immediate effect and influential effect to businesses. Branding strategy to management decision making will translate the change prices into revenue building and ultimately to profits. Pricing is considered as the vital element of basic brand strategies. There have been many high-level trends over the last decade in context developing to pricing that are the key cores to marketing decision and planning. For successful marketing managers they should focus on all behavioral aspect of consumers with respect to price, as not all are the same. Mangers need to understand their niche consumers' with respect to shopping orientation to price, along with needs related to the brand.

Some mangers consider pricing strategies in confiscation from the marketing as part of revenue function only but pricing is the basic marketing pedal with the most immediate and direct business impact. Management decisions to change prices translate into revenue and profit. Pricing is also closely tied to the other elements of brand strategies.

Traditional pricing is considered to start practice from the classical economic notion that the volume demand for a brand or a product will finally decline as the price increases. This may apply to some marketing circumstances, under the hypothesis that "everything else is equal." However, many effective brand strategies give consumers captivating reasons to pay for premium price. The reasons can be related to the brand quality, its ingredients, and its craftsmanship.

\section{Conclusion and our Directed Future}

Gordon Wyner (2014) enlightens that, in many key areas of strategy marketing decision making and implications, knowledge of behaviors impact of consumers can have vital implications for actual decisions making yet to be made by consumers. It can significantly influence the strategic decision and planning, such as types of consumers to choose and its resources allocation. Under many possible circumstances, it can be reasonable to expect advertising can account for the $10 \%$ of the incremental sales. It is also highly doubtful that it can account for the $75 \%$ of the incremental sales.

How markets are designed in terms of segments, competitors, types of brand attributes and choices? Much of the study is exclusive to marketing businesses and research corporations. What is the advantage of having this information? It offers framework for strategic decision planning questions, like:

- What are new propositions for the brands?

- What mangers have to prepare to implement distinctive propositions?

- Where are the future opportunities?

- How value created in the brand/product markets?

- Is the market "crowded"?

Empirical generalizations are useful for strategic market planning. In addition to grounding empirical research on the future availability of data, a balancing perspective would be valuable. It is possible, that conditions could change in the near future and much different advertising will have high contributions to results. Innovative marketing technologies with focused strategies have the potential to accomplish the extraordinary targeting with more niche tactics without resorting to mass advertising and finally achieve extraordinarily high influences. There will be more opportunities on Internet marketing to amalgamate to determine if the practical generalizations have changed. 


\section{References}

Assuncao, J. L., \& Meyer, R. J. (1993). The rational effect of price promotions on sales and consumption. Management Science, 39(5), 517-535.

Barone, M. J., Manning, K. C., \& Miniard, P. W. (2004). Consumer Response to Partial Price Comparisons. Journal of Marketing, 68(July), 37-47. http://dx.doi.org/10.1509/jmkg.68.3.37.34769

Bearden, W. O., Lichtenstein, D. R., \& Teel, J. E. (1984). Comparison Price, Coupon and Brand Effects on Consumer Reactions to Retail Newspaper Advertisements. Journal of Retailing, 60(2), 11-35.

Biswas, A., Bhowmick, S., Guha, A., \& Grewal, D. (2013). Consumer Evaluations of Sale Prices: Role of the Subtraction Principle. Journal of Marketing, 77(July), 49-66. http://dx.doi.org/10.1509/jm.12.0052

Buil, I., Martínez, E., \& Chernatony, L. (2013a). Examining the role of advertising and sales promotions in brand equity creation. Journal of Business Research, 66(1), 115-122. http://dx.doi.org/10.1016/j.jbusres.2011.07.030

Buil, I., Martínez, E., \& Chernatony, L. (2013b). The influence of brand equity on consumer responses. Journal of Consumer Marketing, 30(1), 62-74. http://dx.doi.org/10.1108/07363761311290849

Chen, A., Marmorstein, H., Tsiros, M., \& Rao, A. R. (2012). When More Is Less: The Impact of Base Value Neglect on Consumer Preferences for Bonus Packs over Price Discounts. Journal of Marketing, 76(July), 64-77. http://dx.doi.org/10.1509/jm.10.0443

Dodson, J. A., Tybout, A. M., \& Sternthal, B. (1978). Impact of Deals and Deal Retraction on Brand Switching. Journal of Marketing Research, 15, 72-81.

Donald Lichtenstein. (2014). Retrieved from https://www.ama.org/publications/E-publications/Pages/ama-journal-reader-june-14-pricing.aspx

Gordon Wyner. (2014). Retrieved from http://publications.ama.org/MI_magazine/MI-nov-dec-14/index.html

Gordon Wyner. (2015). Thetrieved https://www.ama.org/publications/MarketingNews/Pages/pricing-brand-strategy.aspx

Hamilton, R., \& Chernev, A. (2013). Low Prices Are Just the Beginning: Price Image in Retail Management. Journal of Marketing, 77(November), 1-20. http://dx.doi.org/10.1509/jm.08.0204

Jain, D. C., \& Vilcassim, N. J. (1991). Investigating household purchase timing decisions: A conditional hazard function approach. Marketing Science, 1-23. http://dx.doi.org/10.1287/mksc.10.1.1

Kahn, B. E., \& Raju, J. S. (1991). Effects of price promotions on variety-seeking and reinforcement behavior. Marketing Science, 10(Fall), 316-337. http://dx.doi.org/10.1287/mksc.10.4.316

Kalwani, M. U., \& Yim, C. H. (1992). Consumer Price and Promotion Expectations. Journal of Marketing Research, 29(1), 90-100.

Lal, R. (1990a). Price promotions: Limiting competitive encroachment. Marketing Science, 9, 247-262. http://dx.doi.org/10.1287/mksc.9.3.247

Lattin, M. J., \& Bucklin, R. E. (1989). Reference Effects of Price and Promotion on Brand Choice Behaviour. Journal of Marketing Research, 26, 299-310.

Miniard, P. W., Mohammed, S. M., Barone, M. J., \& Alvarez, C. M. O. (2013). Retailers' Use of Partially Comparative Pricing: From Across-Category to Within-Category Effects. Journal of Marketing, 77(July), 33-48. http://dx.doi.org/10.1509/jm.10.0534

Rao, R. C. (1991). Pricing and promotions in asymmetric duopolies. Marketing Science IO, 131-144. http://dx.doi.org/10.1287/mksc.10.2.131

\section{Copyrights}

Copyright for this article is retained by the author(s), with first publication rights granted to the journal.

This is an open-access article distributed under the terms and conditions of the Creative Commons Attribution license (http://creativecommons.org/licenses/by/3.0/). 